\title{
Occurrence of Plastic Particles in Procellariiforms, South of São Paulo State (Brazil)
}

\author{
Edison Barbieri* \\ Instituto de Pesca da Secretária da Agricultura e Abastecimento do Estado de São Paulo; C.P. 35; 11990-000; \\ Cananéia - SP - Brasil
}

\begin{abstract}
Seabirds ingest plastic particles floating on the surface of the world's oceans. The birds can ingest plastic particles that they mistakenly identify as prey items. Alternatively, plastics can be taken up in the stomach contents of prey species. Plastic is often passed from parents to chicks in regurgitated food. In this study, individual petrels and albatrosses brought in by the tide onto Ilha Comprida beach between January 2000 and December 2002 were collected. Ilha Comprida, a barrier island in southern São Paulo, Brazil, was traversed by car along a transect of 70 kilometers. A total of 110 birds of 10 species were collected and $64.54 \%$ had plastic particles in their stomach. Frequencies of occurrence were Macronectes giganteus (64.28\%), Thalassarche melanophrys (73.07\%), Thalassarche chlororhinchos (44.44\%), Puffinus puffinus (85.71\%), Puffinus gravis (7.41\%), Puffinus griseus (63.63\%), Fumarus glacialoides (33.33\%), Daption capensis (75\%), Pachyptila belcheri (33.33\%), Procellaria aequinoctialis $(25 \%)$. These results demonstrated the extent of contamination with plastic and the possible harmful effects on seabirds.
\end{abstract}

Key words: Brazil, contamination, Ilha Comprida, plastic, seabirds, Procellariiformes

\section{INTRODUCTION}

Plastic particles floating on the sea surface are ingested by seabirds in many parts of the word (Robards et al. 1995). Surface-feeding birds likely confuse floating particles with prey items (Blight and Burger, 1997). Alternatively, some birds, such as alcids, may ingest plastic particles within the bodies of prey species (Robards et al, 1995). The plastic is often passed from parents to chicks in regurgitated food (Sievert and Sielo, 1993). Furness (1983) suggested that seabirds were likely to be harmed by increased uptakes of PCBs adsorbed to plastic pellets. Bourne (1976) suggested that seabirds might develop blockages of the intestines or ulcers in the stomach, reducing the functional volume of the gizzard and leading to a reduction in digestive capability (Connors and Smith, 1982; Furness, 1985). Other effects may include diminished feeding stimulus, lowered steroid hormone levels and delayed reproduction (Azzarello and Van Vleet, 1987).

According to Blight and Burger (1997), two types of plastic debris are commonly ingested by seabirds: first, manufactured plastic products ("user plastic"), such as bags, bottles, containers and packaging discarded at sea and slowly broken down into smaller fragments; and second, raw industrial plastic pellets, which may occur at sea in densities as high as 8000 per $\mathrm{km}^{2}$ (Pruter, 1987).

\footnotetext{
*Author for correspondence: edisonbarbieri@yahoo.com.br
} 
Seabirds ingest considerable amounts of floating marine litter including plastic (Ryan, 1987). Based on studies of stomach contents, Van Franeker and Meijboom (2002) concluded that the Northern Fulmar ingested almost everything floating on the sea surface. Although Procellariiform species are generally the most contaminated (Day, 1980), amounts of plastic in the gizzard vary greatly between Procellariiform species collected at the same site (Furness, 1983; Cadée, 2002.).

The aim of this work was to study the occurrence and characteristics of plastic particles in the following species: Macronectes giganteus, Thalassarche melanophrys, Thalassarche chlororhynchos, Puffinus puffinus, Puffinus gravis, Puffinus griseus, Fulmarus glacialoides, Dapton capensis, Pachyptila belcheri, Procellaria aecnoquitialis, which were collected dead at Ilha Comprida Island. The goal was to study the extent of contamination with plastic and to determine whether any harmful effects of ingesting plastic could be detected.

\section{MATERIALS AND METHODS}

In the extreme South of São Paulo State, there is an oxbow of Serra do Mar scarp, where the Ribeira do Iguape river hydrographic basin is formed. This estuary marks the northern boundary of estuary-lagoon complex of Cananéia-IguapeParanaguá and in its center, Ilha Comprida is located. This flat expansion covers more than 70 $\mathrm{km}$, averaging $3 \mathrm{~km}$ in width, and is crossed by small brooks, turning it into an attractive area for the birds and several other animals (Fig. 1). Ilha Comprida beach is composed of extensive sandy zones parallel to the coast line, with finely granulated sediments, homogeneous and with low declivity, and therefore, classified as a dissipative type and located in an island of quarternary barrier with recent sedimentation, mainly marine (Suguio and Martins, 1987), formed by the accumulation of sandy material (Tessler, 1988).

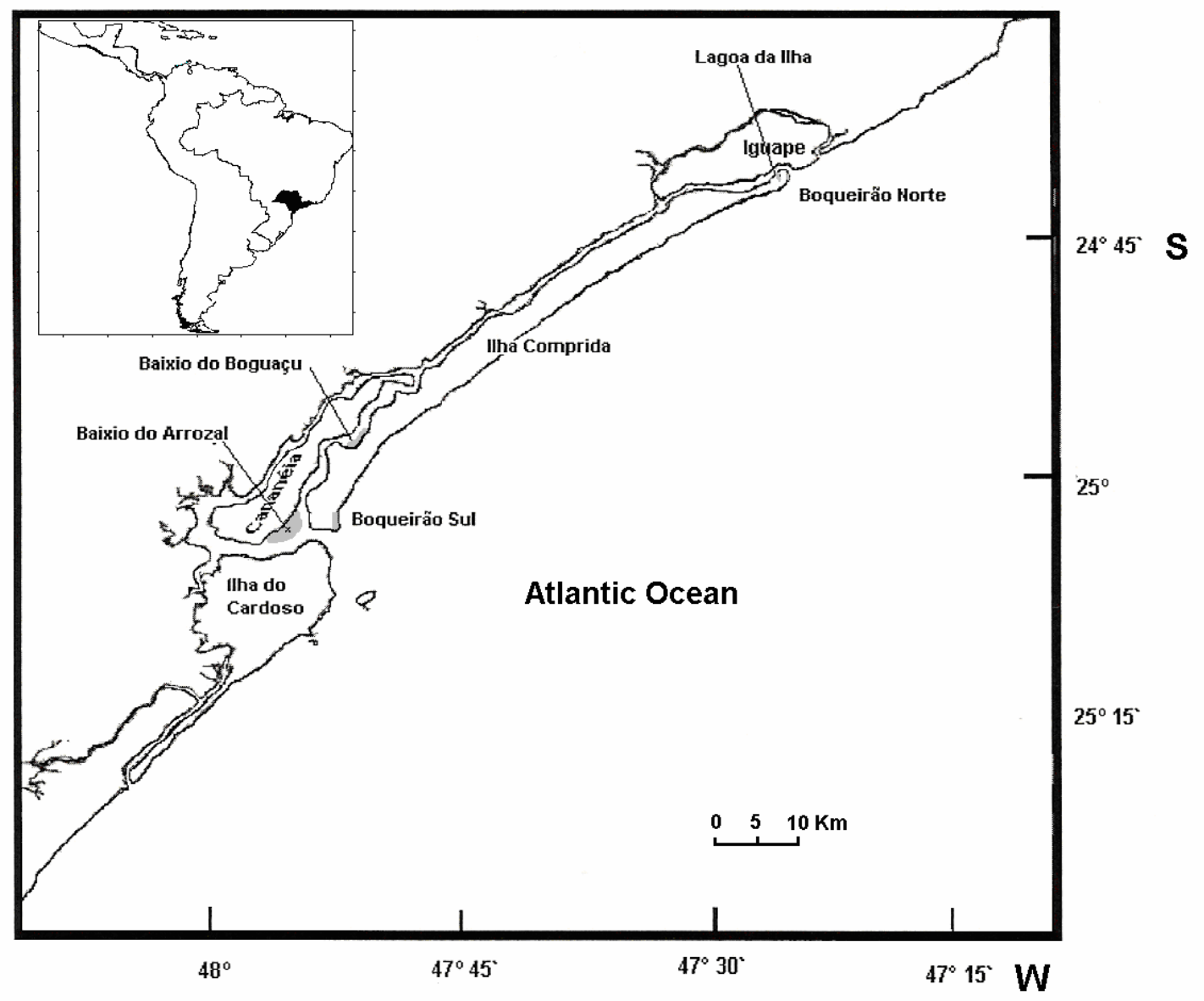

Figure 1 - Southeastern Brazilian coast with the indication of Ilha Comprida Island. 
Stomach samples (gizzards and proventriculi) from 110 seabirds of 10 Procellariiform species were collected between January 2000 and December 2002, along the Ilha Comprida's beach (Fig. 1). The Ilha Comprida beach was covered by car, at $40 \mathrm{~km} / \mathrm{h}$ speed, following a pre-established transect of $70 \mathrm{~km} \times 200 \mathrm{~m}$. The distance covered began always in the southern region of the island (Boqueirão Sul), driving towards north (Canal de Icapara). The birds were identified, weighed, and their length and width was measured. Stomachs were dissected and contents were preserved in the field. Stomachs were later examined in the laboratory for diet composition, and all plastic particles were extracted for analysis. Skeletons, specimens, and tissue samples were archived at the Instituto de Pesca da Secretaria da Agricultura do Estado de São Paulo, Núcleo Cananéia.

Plastic particles were classified according to the size and color. Size classes determined from a particle`s largest dimension were used to categorize the size. Three size categories were recorded: $0.5-0.8 \mathrm{~mm}, 0.7-50 \mathrm{~mm}$, and $1.2-98 \mathrm{~mm}$. Particles were classified as per Day (1980) for shape, with an extra classification to describe whether a particle was tubular, flat or threedimensional. Shape categories included round, oval, cylinder and asymmetrical. Particles were defined according Robards et al. (1995) as pellets (polyethylene particles), user plastic (polypropylene particles), fragments or unrecognizable objects.

\section{RESULTS}

A total of 110 individuals of ten species were collected and $64.54 \%$ of them had plastic particles in their stomachs (Table 1). All the ten species had plastic particles in varying proportions. More than $50 \%$ of individuals of Macronectes giganteus (64.28\%), Thalassarche melanophrys (73.07\%), Puffinus puffinus 85.71\%), Puffinus gravis (72.41\%), Daption capensis (75\%), and Puffinus griseus $(63.63 \%)$ had ingested plastics (Table 1). Less than $50 \%$ of individuals of $T$. chlororhynchos (44.44\%), F. glacialoides (33.33\%), P. belcheri $(33.33 \%)$ and $P$. aequinoctialis $(25 \%)$ had ingested plastics (Table 1).With respect to color, most of the plastic particles ingested by birds were: brown $(26.28 \%)$, white $(12.70 \%)$ and beige (23\%) (Table 2). The less frequent colors were red $(1.75 \%)$ and green $(2.62 \%)$. There was a predominance of the dark colors. Brown, dark beige, gray and black made up to $63.58 \%$ of all ingested plastic particles. The size of plastic particles ingested by the seabirds ranged from 0.5 to $98 \mathrm{~mm}$ (largest dimension). T melanophrys and $M$ giganteus ingested the largest particles (maximum size: $34 X 98 \mathrm{~mm}$ ), largely because they ingested more user plastic. Of the 890 plastic particles examined from 10 species, the majority were of two main types: pellets (35.95\%) and user plastic $(62.92 \%)$, which included plastic container fragments and monofilament line.

Table 1 - Species of the Procellariiforms sampled in Ilha Comprida Island.

\begin{tabular}{lccc}
\hline \multicolumn{1}{c}{ Species } & $\begin{array}{c}\text { Number of birds } \\
\text { sampled }\end{array}$ & $\begin{array}{c}\text { Number of birds } \\
\text { containing plastic }\end{array}$ & $\begin{array}{c}\text { \% of birds containing } \\
\text { plastic }\end{array}$ \\
\hline Macronectes giganteus & 14 & 9 & 64.28 \\
Thalassarche melanophrys & 26 & 19 & 73.07 \\
Thalassarche chlororhynchos & 9 & 4 & 44.44 \\
Puffinus puffinus & 7 & 6 & 85.71 \\
Puffinus gravis & 29 & 21 & 72.41 \\
Puffinus griseus & 11 & 7 & 63.63 \\
Fulmarus glacialoides & 3 & 1 & 33.33 \\
Daption capensis & 4 & 3 & 75.00 \\
Pachyptila belcheri & 3 & 1 & 33.33 \\
Procellaria aequinoctialis & 4 & 1 & 25.00 \\
\hline Total & 110 & 71 & 64.54 \\
\hline
\end{tabular}


Table 2 - Colors composition and size of plastic particles removed from seabirds stomachs (gizzards and proventriculi) collected in Ilha Comprida Island.

\begin{tabular}{|c|c|c|c|c|}
\hline Color & $\mathbf{N}^{\circ}$ Total & $(\%)$ & Weight (g) & $(\%)$ \\
\hline Brown & 240 & $26.28 \%$ & 176 & 27.84 \\
\hline Yellow & 30 & $3.28 \%$ & 29.6 & 4.68 \\
\hline Red & 16 & $1.75 \%$ & 19.2 & 3.03 \\
\hline Green & 24 & $2.62 \%$ & 24.8 & 3.92 \\
\hline Blue & 87 & $9.52 \%$ & 36 & 5.69 \\
\hline Beige & 210 & $23.00 \%$ & 168 & 26.58 \\
\hline White & 116 & $12.70 \%$ & 60 & 9.49 \\
\hline Grey & 64 & $7.00 \%$ & 42.4 & 6.70 \\
\hline Black & 46 & $5.03 \%$ & 28 & 4.43 \\
\hline Mixture & 80 & $8.76 \%$ & 48 & 7.59 \\
\hline Total & 913 & 100 & 632 & 100 \\
\hline
\end{tabular}

The remainder $(1.12 \%)$ of items were unrecognizable plastic pieces (Table 3). However, with respect to weight, a total of $632 \mathrm{~g}, 282 \mathrm{~g}$ were pellets, $347.5 \mathrm{~g}$ of user plastic, representing 44.62 and $54.98 \%$, respectively (Table 3 ). The shapes of the pellets and user plastic removed from seabirds stomachs were predominantly cylindrical $(46.65 \%)$, followed by round $(14.77 \%)$, oval $(10.22 \%)$, and asymmetrical (28.40\%) (Table 4).
The composition of particle types differed greatly among the species (Table 5). Pellets were ingested most by diving species like $P$. puffinus and $P$. gravis, whereas user plastic were more common in surface-feeding species like

T. melanophris and M. giganteus. $P$. belcheri ingested monofilament line as well as smaller user fragments. D. capensis and F. glacialoides ingested slightly more user plastic than pellets.

Table 3 - Total number, weight and length of the "pellets", user plastic removed from seabirds stomachs (gizzards and proventriculus) collected at Ilha Comprida Island.

\begin{tabular}{lccccc}
\hline Types of plastic & Total & $\%$ & Weight $(\mathbf{g})$ & $\%$ & Length $(\mathbf{m m})$ \\
\hline Pellets (polyethilene particles) & 320 & 35.95 & 182 & 28.79 & $0.5-0.8$ \\
User plastic (polypropylene particles) & 560 & 62.92 & 447.5 & 70.08 & $1.2-98$ \\
Unrecognizable plastic pieces & 10 & 1.12 & 2.5 & 0.39 & $0.7-50$ \\
\hline Total & 890 & 100 & 632 & 100 & $0.5-98$ \\
\hline
\end{tabular}

Table 4 - Shape categories of the "pellets" and user plastic removed from seabirds stomachs (gizzards and proventriculus) collected at Ilha Comprida Island.

\begin{tabular}{lcccccc}
\hline \multicolumn{1}{c}{ Shape } & Total & $\boldsymbol{\%}$ & Pellets & $\boldsymbol{\%}$ & User plastic & $\boldsymbol{\%}$ \\
\hline Round & 130 & 14.77 & 55 & 42.30 & 75 & 57.69 \\
Oval & 90 & 10.22 & 41 & 45.55 & 49 & 54.44 \\
Cylinder & 410 & 46.65 & 250 & 60.97 & 160 & 39.02 \\
Asymmetrical & 250 & 28.40 & 14 & 5.6 & 236 & 94.4 \\
\hline Total & 880 & 100 & 360 & - & 520 & - \\
\hline
\end{tabular}


Table 5 - Weight and length of birds sampled with the composition of particle types for each species

\begin{tabular}{lcccc}
\hline Species & $\begin{array}{c}\text { Weight }(\mathbf{K g}) \\
\text { Average }\end{array}$ & $\begin{array}{c}\text { Length }(\mathbf{m}) \\
\text { Average }\end{array}$ & Pellets & User plastic \\
\hline Macronectes giganteus & 4.5 & 2.20 & $14 \%$ & $86 \%$ \\
Thalassarche melanophrys & 3.90 & 2.25 & $27 \%$ & $73 \%$ \\
Thalassarche chlororhynchos & 2.36 & 1.99 & $33 \%$ & $67 \%$ \\
Puffinus puffinus & 0.5 & 0.61 & $57 \%$ & $43 \%$ \\
Puffinus gravis & 0.80 & 1.12 & $66 \%$ & $34 \%$ \\
Puffinus griseus & 0.79 & 1.02 & $71 \%$ & $29 \%$ \\
Fulmarus glacialoides & 0.85 & 1.16 & $53 \%$ & $47 \%$ \\
Daption capensis & 0.78 & 1.03 & $41 \%$ & $59 \%$ \\
Pachyptila belcheri & 0.62 & 0.63 & $76 \%$ & $24 \%$ \\
Procellaria aequinoctialis & 1.28 & 1.3 & $35 \%$ & $65 \%$ \\
\hline
\end{tabular}

\section{DISCUSSION}

A high proportion of the seabirds examined, including every one of the surface-feeding procellariiforms, had plastic particles in the proventriculus or gizzard. In most birds, the quantities found were unlikely to impede the digestion but in $P$. puffinus and T. melanophrys the quantities might have been sufficient to reduce the volume of food in the gizzard, or to affect its assimilation.

Studying stomachs of seabirds, Bright and Burger (1997) encountered a high level of contamination by plastic particles in Procellariiforms from the North Pacific Ocean, and concluded that the feeding surface of those birds was highly affected by this material. The high proportion of contaminated seabirds in this study clearly demonstrated that the feeding surface of Procellariiforms in the South Atlantic Ocean was also affected by the plastic particles.

In this work, the concentration of plastic particles found was higher in M. giganteus (64.28\%), T. melanophris (73.07\%), P. puffinus $85.71 \%), P$. gravis $(72.41), D$. capensis $(75 \%)$, and $P$. griseus (63.63\%) than T. chlororhynchos (44.44\%), F. glacialoides (33.33\%), P. belcheri (33.33\%) and $P$. aequinoctialis. According to Furness and Monaghan (1987), the concentration of plastic particles was always highest in the large Procellariiforms. In general, surface-feeding species took mostly user plastic, whereas diving species ingested more pellets. Also, like Day (1980) and Robards et al. (1995), it was found that larger species tended to ingest larger particles, as did the species that ingested more user fragments, which tended to be larger than pellets.
Many studies have already reported the presence of plastic particles in the stomachof seabirds (Morris, 1980; Fry et al., 1987; Furness 1994; Robards et al, 1995), clearly identifying the problem. The effects of the plastic particles ingested by the seabirds were also studied by Van Franeker (1985), who found that in some cases, the stomachs suffered ulcers and the intestines were obstructed, mainly when large fragments were ingested (Fry et al., 1987; Boersma and Groom, 1993). Other studies indicated that plastic particles interfered with the seabird's digestion. The present study encountered plastic obstructing the intestines of four birds, which might have caused them to die.

With respect to the type of plastic ingested, some differences were observed, although these were difficult to assess statistically because of differences between the studies in the number of each species sampled by different authors. Day (1980) found that about $93 \%$ and Robards et al. (1995) found about that $80 \%$ of ingested plastic were "light" (brown, shades, etc) in color, which was about $63.58 \%$ in this study. This difference was most pronounced among the diving species (P. puffinus and P. gravis). The proportion of total particles that were pellets $(35.95 \%)$ and user plastic fragments $(62.92 \%)$ also varied greatly compared to Day's (75 and 25\%) and Robards et al. (76 and 24\%) studies.

Auman et al. (1998) and Vooren and Brusque (1999) reported that acute plastic ingestion affected $D$. immutabilis chicks in Midway during 1994 and 1995. These studies demonstrated that adults had ingested plastic objects from the sea, which were then transferred with the regurgitated food to their young. Typically, dead young 
individuals which were found in their nests had a ratio $2: 1$ of plastic (g) and had body weight $16 \%$ lower than the birds' young which died by vehicular accident. Sometimes, large plastic pieces wounded or blocked the digestive apparatus. These authors suggested that feeding and digestion had become difficult because of the amount of ingested plastic, causing the affected birds to be weakened. Robards et al. (1995) reported that the ingestion of plastic particles by the seabirds in the North Pacific ocean was a pathway for contamination by toxic compounds, because the plastic surface might absorb oil particles which contained lots of lipid compounds. Vooren and Brusque (1999) reported that the amounts of organochlorine on the plastic surface and the emollients, corants and antioxidants which composed the plastic could have also been toxic to them. Experiments made with the chicken suggested that the plastic particles occurrence in the gut had a high total specific correlation to the increasing of the PCB contamination in adipose tissue (Ryan, 1987).

According to Furness (1994), plastic particles tend to accumulate in specific regions which are influenced by oceanographic process like convergent fronts. These are generlly the regions where the seabirds concentrate to feed, because are plots of high-level primary production that supports a large biomass of invertebrates and vertebrates. Studying gizzards and proventriculi contents of encountered seabirds at the beach, South of Rio Grande (RS), Brazil, Vooren and Chiaradia (1989) had also found polyethylene particles ("nibs") in Procellariiformes. Twentyeight gizzards and proventriculus from a total of 68 petrels examined by Vooren and Chiaradia had polyethylene inside. Ryan (1987) demonstrated that the darker plastic particles are often found inside the seabirds' stomachs, and this was confirmed in the present study. According to Furness (1994), little petrels were less selective with respect to the color of the plastic particles than large albatrosses. Probably For this reason, a great variety of colors of plastic material in the petrel guts was found in this study.

Plastic particles are very resistant to chemical digestion; once in the sea, they keep on floating over its surface throughout many years, where they become an environmental contaminant, which affects mainly the seabirds. Present results clearly demonstrated that the seabirds were good indicators of environments contaminated by plastic (Furness, 1994). Nevertheless, one could reasonably expect that a long-term increase in plastic particle pollution of the seas would be paralleled by an increase in the amount of plastic ingested by the seabirds, and especially by Procellariiforms. It seemed evident that there was a high amount of plastic material contaminating the seabirds of the South Atlantic Ocean.

The growth of the production and the use of plastic since 1960 has resulted in increasing discharges of this material into the oceans, thus leading to the contamination of the seabirds by plastics. The acute and chronic effects of plastic contamination on seabirds are not yet known; hence, further studies about this would be necessary, mainly in the South Atlantic Ocean. The uncertainty over the long-term cumulative effects of this pollution on the seabirds makes it important to monitor plastic ingestion worldwide (Blight and Burger, 1997). Plastics are also found in Antarctic birds, mostly originating from wintering areas outside the continent, though the highest incidence has been noted in chicks of Oceanites oceanicus that died before fledging (Van Franeker and Bell, 1988). This provided further evidence of widespread plastic pollution of the ocean.

Since the extent of plastic contamination could increase, monitoring of levels in Procellariiforms of the South Atlantic Ocean should be undertaken, and some experimental studies should be made to determine the residence time, fate, and physiological effects of ingested plastic.

\section{AKCNOWLEDGEMENTS}

We thank FINEP for supporting this research.

\section{RESUMO}

As aves marinhas ingerem partículas plásticas que ficam flutuando na superfície dos oceanos. Estes animais podem ingerir as partículas plásticas confundindo com as presas. Alternativamente os plásticos podem vir de presas, as quais os contêm em seus estômagos. Os plásticos podem ainda, serem passados dos pais para os ninhegos, quando regurgitam o alimento. Neste trabalho foram coletados indivíduos de petréis e albatrozes ao longo da praia da Ilha Comprida entre janeiro de 2000 a dezembro de 2002. Para tanto a Ilha Comprida, uma ilha de barreira situada no litoral sul 
do Estado de São Paulo, foi percorrida de carro ao longo de um transecção de 70 quilômetros.Foram coletados 110 indivíduos de aves de 10 espécies, das quais $64.54 \%$ continham partículas plásticas em seus estômagos. As Freqüências de ocorrências foram: Macronectes giganteus (64.28\%), Thalassarche melanophrys $(73.0 \%)$, Thalassarche chlororhinchos (44.44\%), Puffinus puffinus (85.71\%), Puffinus gravis (7.41\%), Puffinus griseus (63.63\%), Fumarus glacialoides (3.33\%), Daption capensis (75\%), Pachyptila belcheri (3.33\%), Procellaria aequinoctialis (25\%). Esses resultados demonstram a extensão da contaminação por plástico sobre as aves marinhas

\section{REFERENCES}

Auman, H. J., J. P. Ludwig, J. P. Giesy, and T. Colborn. (1998), Plastic ingestion by Laysan Albatross chicks on Sand Island, Midway Atoll, in 1994 e 1995, pp. 239-244. In G. Robertson and R. Gales (eds.) Albatross: Biology and Conservation. Chipping Norton: Surrey Beatty and Sons.

Azzarello, M. Y. and van Vleet, E. S. (1987), Marine birds and plastic pollution. Mar. Ecol. Progr. Ser. 37: 295-303.

Boersma, P. D. and Groom, M. J. (1993), Conservation of Storm-petrels in the North Pacific. In The Status Ecology, and conservation of Marine Birds of the North Pacific (K. Verneer, K. T. Briggs, K. H. Morgan and D. Siegel-Causey, eds), pp.70-81. Can. Wildl. Serv. Spec. Publi., Ottawa, Canada.

Blight, K. 1. and. Burger, A. F. (1997), Occurrence of plastic particles in seabirds from the Eastern North Pacific. Mar. Pollut. Bull. 34, 323-325.

Bourne, W. R. P. (1976), Seabirds and polluition. In: Marine Polluition (R. Johnson. Ed.), pp. 403-502. Academic Press. London.

Cadée, G. C. (2002) Seabirds and floating plastic debris. Marine Pollution Bulletin. 44: 1294-1295.

Connors, P. G. and Smith, K. G. (1982), Oceanic plastic particle pollution: suspected effect on fat deposition in Red Phalaropes. Mar. Pollut. Bull. 13: 18-20

Day, R. H. (1980) The occurrence andcharacteristics of plastic pollutions in Alaska's marine birds. Thesis, University of Alaska.
Fry, D. M., Fefer, S. and Sielo, L. (1987), Ingestion of plastic debris by Layan Albatross and Wedge-Tailed Shearwaten in the Hawailan Island. In: Plastic in the Sea: Selected papers from the Sixth International Ocean Disposal Symposium (D. A. Wolfe, ed.). Mar. Pollut. 18, 339-343.

Furness, R. W. (1983), Plastic particles in three procellariiforme seabirds the beneguela current . South Africa, Mar. Pollut. Bull. 14: 307-308.

Furness, R. W. (1985), Ingestion of plastic particles by seabirds at Gough Island, South Atlantic Ocean. Env. Pollut. 38, 261-272.

Furness, R. W. and Monaghan, P. (1987), Seabird ecology. Blackie, London.123p.

Furness, R. W. (1994), Birds as monitors of pollutants. In: Birds as Monitors of Environmental Change. Furness R. W and Greenwood, J. J. D. eds. London. $356 \mathrm{p}$.

Morris, R. J. (1980), Plastic debris in the surface waters of the South Atlantic. Mar. Poll. Bull. 11: 164-166.

Prutter, A. T. (1987), Sources, quantities and distribuition of persistent plastic in the marine ocean environment. In Plastic in the Sea: Selected Papers from the Sixth International Ocean Disposal System 9D. A. Wolfe, ed.) Mar. Pollut. Bull. 18, 305-310.

Robards, M. D., Piatt, J. F. and Wohl, K. D. (1995), Increasing frequency of plastic particles ingested by seabirds in the subarctic North Pacific. Mar. Pollut. Bull. 30, 151-157.

Ryan, P.G. (1987), Effects of ingested plastic on seabird feeding: evidence from chickens. Mar. Pollut. Bull. 19: 125-128.

Sievert, P. R. and Sielo, L. (1993), The effects of ingested plastic on growth and survival of albatross chicks. In The Status Ecology, and conservation of Marine Birds of the North Pacific (K. Verneer, K. T. Briggs, K. H. Morgan and D. Siegel-Causey, eds), pp.70-81. Can. Wildl. Serv. Spec. Publi., Ottawa, Canadá.

Suguio, K., Martins, L. (1987), Classificação de costas e evolução geológica das planícies litorâneas quartenárias do sudeste e sul do Brasil. Simpósio sobre Ecossistema da Costa Sul e Sudeste Brasileira, Síntese dos conhecimentos. Academy of Sciences. State of S. Paulo. ACIESP. 54-I: 1-28

Tessler, M. G. (1988), Dinâmica sedimentar quartenária no litoral sul paulista. São Paulo. Tese (Doutorado), Instituto de Geologia da Universidade de São Paulo. $276 \mathrm{p}$. 
Van Franeker, J. A. (1985), Plastic ingestion in the North Atlantic Fulmar. Mar. Pollut. Bull. 16, 367369.

Van Franeker, J. A and Bell, P. J. (1988), Plastic ingestion by petrels breeding in Antarctica . Mar. Pollut. Bull, 19. 672-674.

Van Franeker, J. A., Meijboom, A. (2002), Litter NSV, marine litter monitoring by Northern Fulmars; a pilot study. Alterra-rapport 401:1-72.

Vooren, C.M. and Chiaradia, A. C.(1989), Guia de Albatrozes e petréis do sul do Brasil.Editora Sagra. Porto Alegre. Brasil.p.99.
Vooren, C. M. and Brusque, L. F. (1999), Avaliação e Ações Prioritárias Para A Conservação Da Biodiversidade Da Zona Costeira e Marinhas: Diagnóstico Sobre Aves Do Ambiente Costeiro Do Brasil.http://www.bdt.fat.org.br/workshop/costa/aves.

Received: December 13, 2005; Revised: Setember 20, 2006; Accepted: November 26, 2008. 